\title{
Reading Motivation vis-s-vis Academic Performance
}

\author{
Elysha S. Alvarado, Cerenio Adriatico \\ College of Business and Management, Southern Leyte State University, San Juan, Philippines \\ Email: starylyts@gmail.com
}

How to cite this paper: Alvarado, E.S. and Adriatico, C. (2019) Reading Motivation vis-s-vis Academic Performance. Open Journal of Social Sciences, 7, 92-106. https://doi.org/10.4236/jss.2019.76007

Received: May 7, 2019

Accepted: June 7, 2019

Published: June 10, 2019

Copyright (C 2019 by author(s) and Scientific Research Publishing Inc. This work is licensed under the Creative Commons Attribution International License (CC BY 4.0).

http://creativecommons.org/licenses/by/4.0/

\begin{abstract}
Abundant literature can be sourced out from different authorities about reading motivation, yet little work can be traced between this component and the academic achievement. Hypothesizing that motivation has a significant relationship to success, this study attempted to investigate such a particular connection. The researchers used a modified version of the Motivation for Reading Questionnaire (MRQ) administered to 82 Grade III pupils, of which the first half were required to answer the questions for pilot testing. For the correlation test, the raw scores of quarterly academic grades of pupils were utilized. Statistical results identified that reading motivation was not significantly related to the academic achievement of the pupils. One that is carried out is the development of learners as readers. In this manner, the researchers suggested that teachers should continue nurturing of enhancing the reading skills of pupils by implementing different strategies to improve the academic performance of the learners.
\end{abstract}

\section{Keywords}

Motivation for Reading Questionnaire, Correlation Test, Reading Strategies

\section{Introduction}

This study explored the different domains reading motivation has and how the students find its direct relation to their academic performance in five academic areas such as English, Science, Math, TLE, and Makabayan. The 2005 National Achievement Test for secondary students with unsatisfactory result in English, Science, and Mathematics, which was traced mainly to their poor reading comprehension [1], prompted this study. In educational psychology and reading education, reading motivation played a vital role in the academic performance of the learners. The domain-specific nature of motivational constructs such as be- 
liefs, values, and goals, influences reading motivation. This is the idea that children learn to read more when they feel competent and efficacious in reading [2].

Values encompass valuing for achievement, intrinsic-extrinsic motivation, and achievement goals, including performance and learning goals. Motivational processes, on the other hand, represent the foundation for coordinating cognitive goals and strategies in reading. This concept is found consistent with both a cognitive science of text and a situated account of the acquisition of expertise [3] [4] as well as the development of intrinsic motivation [5]. In other words, becoming excellent and active reader involves attunement of motivational processes with cognitive and language processes in reading [2]. It asserted that students with high motivation would seek books to provide satisfaction, which eventually develops their cognitive skills. This idea is consistent with both the cognitive science of reading and the situated account of the acquisition of expertise [3]. In practice, becoming an excellent reader involves attunement of motivational processes with cognitive and language processes in reading.

Meanwhile, Memorandum No. 158, series of 2007 was issued by the Secretary of Education in response to the poor performance on reading comprehension results as shown in the 2007 National Achievement Test. The memorandum pointed out that reading and writing as tools for learning need to be strengthened to effect the desired outcome of students' performances in terms of improved communication skills in both oral and written language. A similar memorandum order was also issued by the Department of Education during the preceding year to determine the competencies of the graduating elementary pupils covering the five subjects of Makabayan (history), English, Filipino, Science, and Mathematics.

Several studies previously conducted merely focused on the areas of motivation [2] [6] [7], reading [8] [9] [10], achievement goals [11], reading alternate assessment [12], and cognitive of reading [13] [14]. Investigating between reading abilities and academic performance has not been studied at length. In this paper, the researchers yearned to explore the factors motivating the pupils to read and identify the significant relationship between reading and academic performance.

\section{Short Literature Review}

[2] hypothesized that student's motivation might be, to some extent, domain specific. For instance, some students may be motivated to read but not to listen, speak, or write. Based on this hypothesis, they developed the Motivation Reading Questionnaire (MRQ) to investigate the construct of reading motivation. In developing the MRQ, proponents consulted several general motivational theories in psychology because they thought that research on reading motivation had been based only on a few components identified by general motivation theorists.

One influential general motivation model that [15] consulted was the Expectancy-Value Theory, which links achievement behavior directly to individuals' 
expectancy related beliefs and task-value beliefs. That is the perceived probability of success, and the value of individual are associated with specific tasks are critical determinants of motivation.

[16] Theory for Cognitive Development has something to do with motivation done in context with social engagements with the individual. This theory is governed by the principles that cognitive development requires social interaction. Furthermore, [16] argued on the idea that the potential for cognitive development depends upon the "Zone of Proximal Development" (ZPD)—a level of development attained when children engage in social behavior. Full development of ZPD depends upon entire social interaction with the environment. The range of skill that can be developed with adult guidance or peer collaboration exceeds what can be attained alone.

To further structure a strong basis of the study, [16] Theory on Cognitive Development could be significantly associated with the Self-Determination Theory (SDT) which is a general theory of human motivation concerned with the development and functioning of personality within social contexts. The approach focuses on the degree to which human behaviors are volitional or self-determined. This means that the degree to which people endorse their actions at the highest level of reflection and engage in the activities with a full sense of choice.

Researchers found the motivation to be multi-faceted. It means that within an individual, some types of motivation will be stronger than others. In motivation researches, investigators have focused primarily on task-mastery orientation and performance orientation. Individuals with a mastery orientation seek to improve their skills and accept new challenges. They are dedicated to content understanding and learning soft skills.

Researchers now thought that there are two common motivations: intrinsic and extrinsic [17]. That is the only area of motivation that they seem to agree. Intrinsic motivation means that the student wants to complete the task because they are interested in their own while extrinsic motivation comes from compliance only for teachers, parents, or peers.

\section{Conceptual Framework}

The study is based on the Reading Motivation Theory [2], Perspective on Cognitive Development [16], and the Self-determination Theory [5]. These theories stated that intrinsic motivation of the learner coupled with self-determination would definitely result to higher cognitive development.

It is also anchored on Department of Education Memorandum No. 158, series 2007 directing a whole school approach to mastery reading and writing for successful learning in the secondary level. The memorandum was the direct move of the department in response to the poor performance on reading comprehension results in the 2007 National Achievement Test. The memorandum pointed out that reading and writing as tools for learning need to be strengthened to effect the desired outcome of students' performances in terms of improved communi- 
cation skills in both oral and written language. Figure 1 which presents the schematic diagram of the theoretical-conceptual framework describes the theories, legal basis, reading motivation dimensions and the five subject areas for academic achievement.

\section{Methodology}

The study used the descriptive-correlational design to determine the students' reading motivation and its relationship to their academic achievement. It utilized the adapted Motivation for Reading Questionnaire (MRQ) [2] with some modifications focused on the eleven dimensions of reading efficacy, challenge, curiosity, aesthetics, importance, compliance, recognition, grades, social, competition and work avoidance.

The study was conducted at St. Bernard Central School of St. Bernard, Southern Leyte, Philippines during Academic Year 2013-2014. The school covers a three-hectare lot adjacent to the town proper. The school has a population of 700 students coming from the different barangays of the municipality.

Prior ethical approval was obtained by the researchers from the school authorities of the concerned elementary school before the conduct of the study. The actual results of the academic achievement data covering from first to third

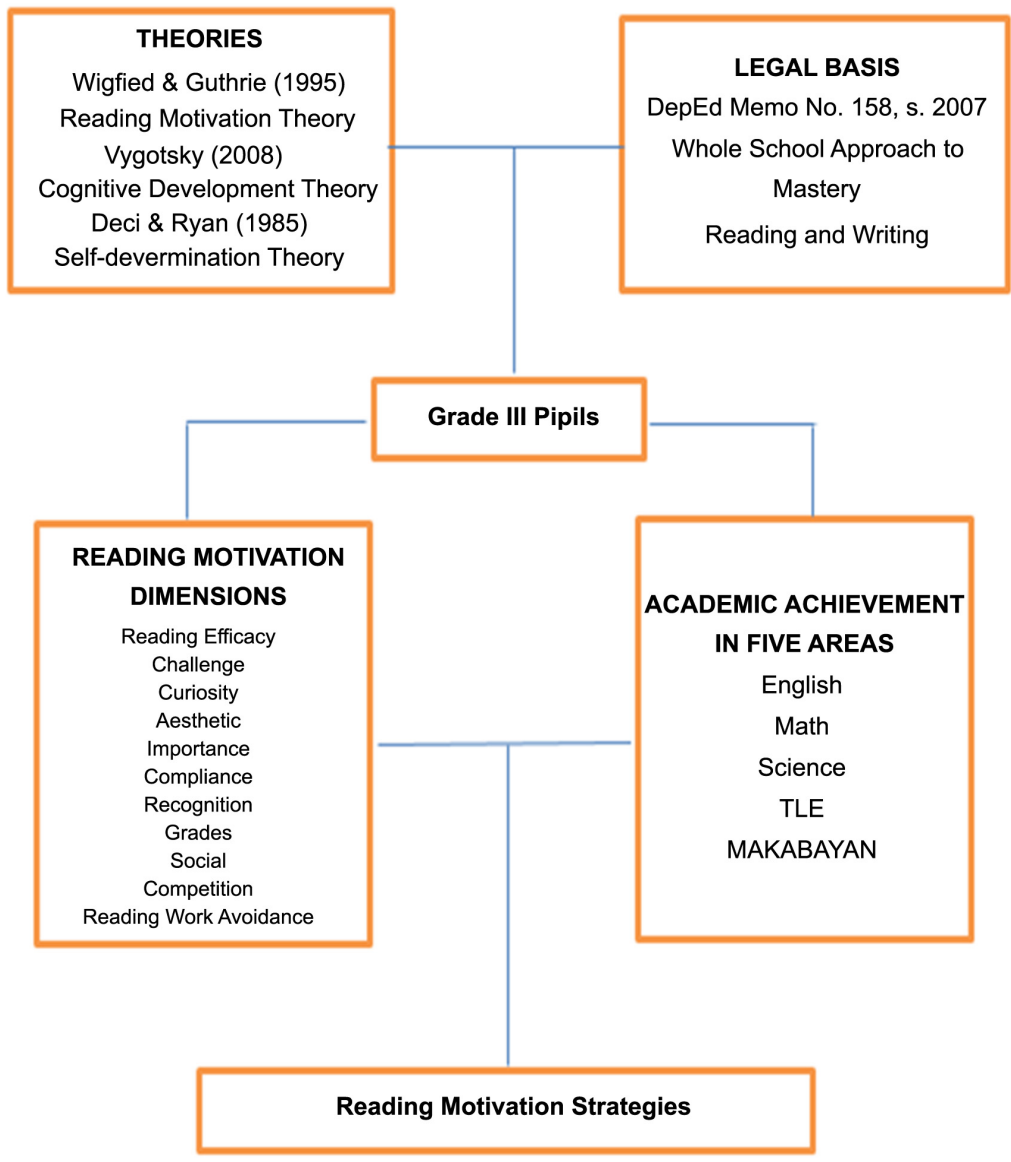

Figure 1. The conceptual framework of the study. 
quarterly test grades of the pupils were requested from their respective class advisers upon the presentation of a written notice of approval from the school principal-all the 82 pupils involved in the study comprised of the two sections of Grade III classes.

In the selection of the respondents, all the names of the pupils were individually written on a piece of paper and were rolled out. The researchers then randomly selected 41 pupils who answered the questionnaire for pilot testing. The other half were instructed to answer the final survey. The researchers conducted an orientation before the respondents answered the questions. The questions were interpreted into their mother tongue to ensure they fully understood the different indicators. Frequency count and the ranking system was used as the basis in determining which element in the various reading motivation domains was prominent. A Point-Biserial Correlation Coefficient was also used to test the level of significance on the variables, particularly on the area of reading work avoidance. Table 1 presents the profile of the grade III pupils involved in the study.

\section{Results and Discussion}

Table 2 shows the reading motivation of students in terms of efficacy. It pertains to the ability of a person to judge his or her capabilities concerning a particular task. If a student has high self-efficacy, he or she sees reading as something he or she can master if he or she works diligently. The very reason these students rated indicator six as their primary choice was to obtain higher grades at the end of the school year. Besides, they also promised to do well in reading in the ensuing year. Of course, the other factors ranked by the pupils also provided pieces of evidence to their levels of awareness on their motivation toward improving their reading habits. The results here complimented the previous findings [18] who ascertained that the higher standards maintained by the teacher in engaging pupils

Table 1. The profile of the respondents of the study.

\begin{tabular}{ccc}
\hline Gender & Population & Sample \\
\hline Male & 46 & 23 \\
Female & 36 & 18 \\
Total & 82 & 41
\end{tabular}

Table 2. Reading motivation in terms of reading efficacy.

\begin{tabular}{lccc}
\hline \multicolumn{1}{c}{ Indicators } & \multicolumn{2}{c}{ Frequency } & \multicolumn{2}{c}{ Rank } \\
\cline { 2 - 4 } & Yes & No \\
\hline 1) Do well in reading next year & 37 & 4 & $2^{\text {nd }}$ \\
2) Don't know why sometimes get low grades in reading & 25 & 16 & $5^{\text {th }}$ \\
3) Good reader & 26 & 15 & $4^{\text {th }}$ \\
4) Sometimes don't feel as smart as others in reading & 33 & 8 & $3^{\text {rd }}$ \\
5) Learn more from reading than most students in the class & 26 & 15 & $4^{\text {th }}$ \\
6) Know how to get good grades if desired & 39 & 2 & $1^{\text {st }}$ \\
\hline
\end{tabular}


to consistently read the study materials assigned either as homework or quizzes would significantly improve both their reading abilities and academic performance. Although motivation is essential to reading instruction, it is not enough to know how to read. A student should go beyond the crucial reading ability, which is comprehension. [12] explained that children who frequently read frequently always have the opportunity of developing their potentials to become academic achievers. Accordingly, reading motivation is often cited as an essential factor for all students of becoming proficient readers.

Table 3, which shows reading motivation in terms of challenge, is another social factor that impacts on reading. In this area, $90 \%$ of the students selected they were interested in looking into unfamiliar words. Their choice indicated their hunger in improving their vocabulary abilities. Besides, they also ranked indicator eight as the second choice signifying they would continue reading a particular book no matter how difficult the words contained in every paragraph as long as they find the story to be exciting. The top two choices made by respondents supported the findings [19], confirming that proficient readers are motivated by mastering from simple to complex text to develop an intrinsically motivated behavior.

The findings in Table 4 showed three crucial learnings; namely, the passion of the students to read about new things, their interest in reading about their favorite subjects and most importantly, learning further information on topics they found interesting. The data in this table revealed that most pupils are curious of

Table 3. Reading motivation in terms of challenge.

\begin{tabular}{lccc}
\hline \multicolumn{1}{c}{ Indicators } & \multicolumn{2}{c}{ Frequency } & \multirow{2}{*}{ Rank } \\
\cline { 2 - 3 } & Yes & No & \\
\hline 1) Like hard, challenging books & 26 & 15 & $6^{\text {th }}$ \\
2) Need my parents to help in reading homework & 28 & 13 & $5^{\text {th }}$ \\
3) Like to look up words not known & 34 & 7 & $1^{\text {st }}$ \\
4) Read difficult materials if the project is interesting & 31 & 10 & $4^{\text {th }}$ \\
5) Like it when the question in books makes one think & 32 & 9 & $3^{\text {rd }}$ \\
6) Don't like it when getting difficult reading & 13 & 28 & $7^{\text {th }}$ \\
7) Usually learn difficult things by reading & 32 & 9 & $3^{\text {rd }}$ \\
8) Don't care how hard it is if the book is interesting & 33 & 8 & 2 nd \\
\hline
\end{tabular}

Table 4. Reading motivation in terms of curiosity.

\begin{tabular}{lccc}
\hline \multirow{2}{*}{ Indicators } & \multicolumn{2}{c}{ Frequency } & Rank \\
\cline { 2 - 3 } & Yes & No & \\
\hline 1) Might read more about it if teacher discusses something interesting & 35 & 6 & $3^{\text {rd }}$ \\
2) Like to read about favorite subjects & 37 & 4 & $2^{\text {nd }}$ \\
3) Read to learn new information about topics that is interesting & 38 & 3 & $1^{\text {st }}$ \\
4)Sometimes get lose track of time if reading an interesting topic & 32 & 9 & $4^{\text {th }}$ \\
5) Read about hobbies to learn more about hem & 37 & 4 & $2^{\text {nd }}$ \\
6) Like to read about new things & 38 & 3 & $1^{\text {st }}$ \\
7) Don't like to read books about living things & 18 & 23 & $5^{\text {th }}$ \\
\hline
\end{tabular}


reading on items that are genuinely engaging such as the ecosystem of living things, relating to factors surrounding the environment, knowing themselves and adventure stories to mention a few. The results here encourage both teachers and parents to be cautious in providing appropriate reading materials to elementary pupils so that the latter would continuously increase their interest in reading books and magazines suitable for their tender age. [20] validated that most of the pupils are curious enough to venture into reading delicate materials to accumulate thorough knowledge and understanding a particular item of interest.

The observations developed in Table 5 showed the preferences of students in reading stories full of interesting characters, making friends and their happiness earned in reading lots of adventure stories in terms of aesthetics. The results here indicated that pupils have fun and fondness in reading materials which are replete with morals and beauty from the setting to the characters, stories becoming realistic and scenes that engage fantasy, adventure, and discovery that would truly captivate their imagination and interest. [20] affirmed good books could inspire children, expand their imaginations, and help them become better learners.

Table 6 presents the reading motivation of students in terms of importance. The two indicators in this table revealed the students are very much aware in developing their skills in becoming a good reader and enabling themselves to decipher new words and phrases they come across in everyday conversation. Accordingly, reading is an activity that involves a higher level of concentration that adds value to the conversational skill of the reader. These findings validated the claim [21] that reading is said to help the vocabulary enhancement of a reader significantly; has to be developed at an early stage of a person's life for it would help in mental development including stimulating the muscles of the eyes.

Table 5. Reading motivation in terms of aesthetics.

\begin{tabular}{lccc}
\hline \multicolumn{1}{c}{ Indicators } & \multicolumn{2}{c}{ Frequency } & Rank \\
\cline { 2 - 3 } & Yes & No & \\
\hline 1) Read stories about fantasy and make believe & 21 & 20 & $6^{\text {th }}$ \\
2) Like mysteries & 34 & 7 & $4^{\text {th }}$ \\
3) Like stories with interesting characters & 40 & 1 & $1^{\text {st }}$ \\
4) Make pictures in mind when reading & 34 & 7 & $4^{\text {th }}$ \\
5) Feel like making friends with people & 38 & 3 & $2^{\text {nd }}$ \\
6) Read a lot of adventure stories & 35 & 6 & $3^{\text {rd }}$ \\
7) Enjoy a long, involved story or fiction book & 29 & 12 & $5^{\text {th }}$ \\
\hline
\end{tabular}

Table 6. Reading motivation in terms of importance.

\begin{tabular}{lcccc}
\hline \multirow{2}{*}{ Indicators } & \multicolumn{2}{c}{ Frequency } & \multirow{2}{*}{ Rank } \\
\cline { 2 - 3 } & Yes & No & \\
\hline 1) Being a good reader is important & 38 & 3 & $1^{\text {st }}$ \\
2) Being a good reader is important compared to other Activities & 37 & 4 & $2^{\text {nd }}$ \\
\hline
\end{tabular}


As observed, children who started reading at an early age tend to have excellent language skills and grasp the variances in phonics much better. As such, reading habit as a vital thing in the life of a person has to be nurtured at the very early stage in a person's life.

Table 7 presents the pupils reading motivation in terms of compliance. The findings in this table showed the intrinsic and extrinsic reading motivation of students. Inherent in the sense that students motivate themselves to read to gain new and practical knowledge. Extrinsic motivation, on the other hand, encourages the students to do reading to comply with the requirements set on a particular subject. The preference made by the students is somewhat odd since they were only forced to read a story, poem, exercises, assignments, and the like for compliance purposes only. Had they value the importance of reading, they could have chosen indicator 4. Extrinsic reading motivation is earlier supported in the study [17] in which students wanted to complete the task not because they were interested but just for compliance with the need of the teachers, parents, and peers.

The results obtained in Table 8 showed 99\% of the respondents like having recognized as a good reader. The preference made the students denoted that recognition remained a critical motivating factor for them to read more. It is a type of extrinsic motivation resorted by many teachers as a quick fix to get students focused. The teachers typically do positive reinforcement in the hope of continuing the interest of students in reading the assigned materials or tasks.

Table 7. Reading motivation in terms of compliance.

\begin{tabular}{lccc}
\hline \multicolumn{1}{c}{ Indicators } & \multicolumn{2}{c}{ Frequency } & Rank \\
\cline { 2 - 3 } & Yes & No \\
\hline 1) Do little schoolwork as possible in reading & 37 & 4 & $4^{\text {th }}$ \\
2) Reading because it is needed & 39 & 2 & $2^{\text {nd }}$ \\
3) Performing reading work carefully is important & 38 & 3 & $3^{\text {rd }}$ \\
4) Read things that are not assigned & 32 & 9 & $6^{\text {th }}$ \\
5) Always do reading works exactly as the teacher wants it & 31 & 10 & $7^{\text {th }}$ \\
6) Finishing every reading assignment is very important & 40 & 1 & $1^{\text {st }}$ \\
7) Always try to finish reading on time & 38 & 3 & $3^{\text {rd }}$ \\
8) Do school work so that the teacher can make sure attention was given & 36 & 5 & $5^{\text {th }}$ \\
\hline
\end{tabular}

Table 8. Reading motivation in terms of recognition.

\begin{tabular}{|c|c|c|c|}
\hline \multirow{2}{*}{ Indicators } & \multicolumn{2}{|c|}{ Frequency } & \multirow{2}{*}{ Rank } \\
\hline & Yes & No & \\
\hline 1) Like having recognized as good reader & 40 & 1 & $1^{\text {st }}$ \\
\hline 2) Like when told by friends as good reader & 38 & 3 & $2^{\text {nd }}$ \\
\hline 3) Like to get compliments for reading & 35 & 6 & $4^{\text {th }}$ \\
\hline 4) Getting good comments on reading paper is important & 37 & 4 & $3^{\text {rd }}$ \\
\hline 5) Parents give gifts when doing well in reading & 34 & 7 & $5^{\text {th }}$ \\
\hline 6) Happy when recognized doing a reading task & 37 & 4 & $3^{\text {rd }}$ \\
\hline 7) Like when told by parents good job of reading & 34 & 7 & $5^{\text {th }}$ \\
\hline 8) Don't care about getting rewards being a good reader & 20 & 21 & $6^{\text {th }}$ \\
\hline
\end{tabular}


Praise and rewards are few examples of positive reinforcement, are a kind of extrinsic motivation; thus, teachers need to be cautious in handling this recognition in the classroom. Arguably, some pupils young as they are, still need this kind of motivation. If this method would help lift a pupil up, then it has to be implemented for the sake of getting better results from the students. These complete results support the findings [19] the need to provide constructive praise reinforcing the learning goal of students though not long lasting.

The responses presented in Table 9 signified that 95\% of the pupils' perceived reading generally improve their grade. The respondents also claimed their parents asked about their classes in reading and by doing well in this aspect, constitute higher grades earned after the academic year. The results here verified the findings [22] evaluation in reading tasks should be directed toward student effort. When students are individually evaluated regarding their efforts exerted in the class, they are likely to be task-centered rather than grade centered students.

The results presented in Table 10 revealed that the students are more than willing to tell their families on the books, textbooks, magazines, articles, and other items they read. The social motivation for reading relates to the interpersonal and community activities involving the students. Children who like to share books with peers and participate responsibly in a community of learners have the likelihood of becoming intrinsically motivated readers. This attitude is of paramount importance because social motivation leads to an increase in both amount and high achievement in reading. The results in this particular area

Table 9. Reading motivation in terms of grades.

\begin{tabular}{lccc}
\hline \multicolumn{1}{c}{ Indicators } & \multicolumn{2}{c}{ Frequency } & Rank \\
\cline { 2 - 3 } & Yes & No & \\
\hline 1) Doing well in reading is seen in grades & 36 & 5 & $3^{\text {rd }}$ \\
2) Getting graded in reading brings nervousness & 19 & 22 & $6^{\text {th }}$ \\
3) Like to get good grades in reading & 39 & 2 & $1^{\text {st }}$ \\
4) Getting high grades in reading brings pride & 33 & 8 & $4^{\text {th }}$ \\
5) Finding out reading grade is always looked up to & 31 & 10 & $5^{\text {th }}$ \\
6) Reading improves grades & 39 & 2 & $1^{\text {st }}$ \\
7) Parents asked about reading grade & 38 & 3 & $2^{\text {nd }}$ \\
\hline
\end{tabular}

Table 10. Reading motivation in terms of social.

\begin{tabular}{lccc}
\hline \multicolumn{1}{c}{ Indicators } & \multicolumn{2}{c}{ Frequency } & Rank \\
\cline { 2 - 3 } & Yes & No & \\
\hline 1) Visit library often with family & 20 & 21 & $5^{\text {th }}$ \\
2) Often read to brother or sister & 29 & 12 & $4^{\text {th }}$ \\
3) Like to trade things to read with friends & 36 & 5 & $2^{\text {nd }}$ \\
4) Sometimes read to parents & 36 & 5 & $2^{\text {nd }}$ \\
5) Talk to friends about what is read & 30 & 11 & $3^{\text {rd }}$ \\
6) Like to help friends with schoolwork in reading & 36 & 5 & $2^{\text {nd }}$ \\
7) Don't like reading with other students & 18 & 23 & $6^{\text {th }}$ \\
8) Tell family about what is read & 37 & 4 & $1^{\text {st }}$ \\
\hline
\end{tabular}


supported the findings [2] [7] [23] children with pro-social goals tended to perform better in school academics compared to children who are not keen of imbibing social goals. Besides, [23] found out that actual achievement between high and low performers significantly differ. High achievers combined active social and academic goals, whereas low achievers focused more on social goals.

The results of the reading motivation of the pupils in terms of competition presented in Table 11, explained every grade schooler wanted to be recognized as best in reading. They also have the willingness to work harder in reading to perform better than their friends. The children also perceived daily reading would make them capable of becoming a good reader in the fields of sight word recognition, vocabulary, verbal fluency, reading comprehension, and general knowledge, among others. These findings generally supported the claims [13] [15] [24]-[29] that the two relatively distinct and well-established indicators of reading motivation: competency beliefs and goal orientation allow the children to learn frequently which subsequently their mastery of the subject matter.

The perceptions of the students presented in Table 12 mirror the present condition of the entire Philippine society. As reflected in the responses, they do not like to read out loud in class for fear of being ridiculed or making fun of especially when they commit mistakes in pronouncing the words or phrases. It is the very reason the children do hesitate to read English material sources inside the class to avoid mistakes. Hence, many of the students from the elementary to tertiary level lack the confidence of reading or presenting their reports in front of their classmates, thus, qualifying themselves as merely poor readers. Their lack of motivation to reading validated the results of previous studies [14] [29]

Table 11. Reading motivation in terms of competition.

\begin{tabular}{|c|c|c|c|}
\hline \multirow{2}{*}{ Indicators } & \multicolumn{2}{|c|}{ Frequency } & \multirow{2}{*}{ Rank } \\
\hline & Yes & No & \\
\hline 1) Try to get more answers right than friends & 34 & 7 & $3^{\text {rd }}$ \\
\hline 2) Like being the best in reading & 39 & 2 & $1^{\text {st }}$ \\
\hline 3) Like to finish reading before other students & 32 & 9 & $4^{\text {th }}$ \\
\hline 4) Like being the only one knows an answer in something read & 30 & 11 & $5^{\text {th }}$ \\
\hline 5) Hate when others read better & 12 & 29 & $6^{\text {th }}$ \\
\hline 6) Like to see names on a list of good readers & 32 & 9 & $4^{\text {th }}$ \\
\hline 7) To see names on a list of good readers is important & 34 & 7 & $3^{\text {rd }}$ \\
\hline 8) Willing to work hard to read better than friends & 35 & 6 & $2^{\text {nd }}$ \\
\hline
\end{tabular}

Table 12. Reading motivation in terms of reading work avoidance.

\begin{tabular}{llll}
\hline \multicolumn{1}{c}{ Indicators } & \multicolumn{2}{c}{ Frequency } & Rank \\
\cline { 2 - 3 } & Yes & No & \\
\hline 1)Don't like to read out loud in class & 29 & 12 & $1^{\text {st }}$ \\
2) Don't like vocabulary questions & 26 & 15 & $2^{\text {nd }}$ \\
3) Complicated stories are no fun & 25 & 16 & $3^{\text {rd }}$ \\
4) Don't like having to write about what is read & 20 & 21 & $4^{\text {th }}$ \\
\hline
\end{tabular}


low-skilled readers consider reading rather difficult, becoming pessimistic, view themselves as less competent readers and most often avoid classroom learning activities. Hence, teachers should find ways of boosting reading motivation among children.

The profile of the academic achievement test presented in Table 13 denoted the mean scores of the Grade III pupils were just within the average bracket. The data also revealed not a single subject received above average mean and its corresponding adjectival description. Although both English and Filipino subjects rank first having a mean score of 85, the Science subject had the lowest mean rating of 81 . All these subjects are considered reading matters according to the Department of Education standards, yet the results achieved by the pupils proved otherwise. For instance, the Makabayan subject is the history subject delivered in Filipino required lots of reading skills since it covers the historical ups and downs of the country but the results of the achievement test showed the lack of mastery in all the topics included in the examination. The pupils were also deficient in solving mathematical problems for they answered the questions without understanding the methods or procedures.

Regarding the science subject, the pupils lacked a thorough understanding of the concepts shared in the class. In general, the improvement of the country principally anchors on science and mathematics endeavors. Without improving these areas, the country's path to development would lead to nowhere. The apparent lack of reading competencies among the pupils is the primary reason for the poor achievement earned in the examination. Further, the poor results are indicative of the lack of motivation in reading. These findings ascertained [19] [30] motivation in reading as the principal component of engagement in reading should be nurtured at an early childhood stage to harness their interest in understanding concepts, methods, and procedures including the practical application of knowledge in the classroom and the community.

The results summarized in Table 14, indicated the learners were all positive on their views of the ten reading motivation dimensions. However, they all despised on work avoidance dimension (don't like to read out loud in class) indicating their fear of being the subject of ridicule if they err in pronouncing the words or phrases correctly. Children as they are like to be recognized by their teachers, get noticed of every reading effort they did and more importantly, their intention of sharing their understanding on materials they read to their family

Table 13. The academic achievement profile relative to the different subject areas.

\begin{tabular}{ccl}
\hline Subject Area & Mean Grade & Description \\
\hline English & 85 & Average \\
Mathematics & 83 & Average \\
Science & 81 & Average \\
Filipino & 85 & Average \\
Makabayan (History) & 83 & Average \\
\hline
\end{tabular}

Legend: Grade Description: 90 - 100 Above Average; 75 - 89 Average; Below 75 Below Average. 
circles. Surprisingly, they still lacked the confidence of reading out loud in front of their classmates and teacher.

\section{Testing of significant relationships}

The results described in Table 15 displayed the existence of a very weak correlation between reading motivation and academic achievement. The reasons for the no significant relationship could be attributed to the following conditions. First, the avoidance dimension has no bearing on academic achievement. Second, other domains tested reflected no variations on the academic achievement examination. Third, none of the indicators have been answered thoroughly "Yes" by the respondents. Fourth, all the mean scores of the pupils received on the subjects taken were all on "average" mark. Fifth, there was no second examination administered to the pupils. Had the students were unanimous in providing "Yes" to all the indicators and achieved above average during the examination of the five subject areas, a strong relationship between the two variables could have been attained. Unfortunately, the results of the correlation test did not conform to the earlier claims [6] that pupils with very high motivation, task-oriented and possessing very high self-efficacy tend to be active readers and high academic achievers.

\section{Conclusions}

This study generally looked into the relationship between the reading motivation of the pupils and their academic achievement. Reading motivation is one vital factor for the enhancement of the academic performance of students. Both reading

Table 14. Summary results of dimensions and indicators selected.

\begin{tabular}{|c|c|}
\hline Reading Motivation Dimension & Indicator \\
\hline * Reading efficacy & ${ }^{*}$ If desired, good grades can be acquired \\
\hline * Challenge & ${ }^{\star}$ Like to look up words not known \\
\hline * Curiosity & ${ }^{\star}$ Read to learn new information about interesting topics \\
\hline * Aesthetics & ${ }^{*}$ Like stories with interesting characters \\
\hline * Importance & * To be good reader is important \\
\hline * Compliance & * Finishing every reading assignment is very important \\
\hline * Recognition & ${ }^{*}$ Like having recognized by the teacher of being good reader \\
\hline * Grades & ${ }^{\star}$ Like to get good grades in reading \\
\hline$*$ Social & * Like to tell the family about what was read \\
\hline * Competition & ${ }^{*}$ Like being the best in reading \\
\hline * Work avoidance & ${ }^{*}$ Don't like to read out loud in class \\
\hline
\end{tabular}

Table 15. Correlation between reading motivation and academic achievement.

\begin{tabular}{|c|c|c|c|c|}
\hline Variable & $\begin{array}{c}\text { Point-Biserial Correlation c } \\
\text { Coefficient }\end{array}$ & T-computed value & t-tabular value & interpretation \\
\hline $\begin{array}{l}\text { Reading motivatio } \\
\text { (avoidance) } \\
\text { And Academic } \\
\text { Achievement }\end{array}$ & 0.15 & 0.95 & 2.04 & Not significant \\
\hline
\end{tabular}

Legend: $0</ \mathrm{r} /<0.3=$ weak correlation; $0.3</ \mathrm{r} /<0.7=$ moderate correlation; $/ \mathrm{r} />0.7=$ strong correlation. 
abilities and habits have social significance as well as individual values that transform the child into an adept reader having all the intrinsic and extrinsic motivational values. Although the indicators of the reading motivation were perceived positively by the respondents, they were quite hesitant about reading confidently in front of their classmates and teachers. Thus, the overall results suggested that reading motivation had no significant relationship with the academic performance of the pupils. Given the consistent findings, the researchers recommend the following:

1) Teachers should continue giving motivation in reading activities to achieve above average scores of pupils.

2) Teachers may adopt different reading strategies geared toward improving the performance of pupils during the achievement examination.

3) Where applicable, convert the classrooms into a gallery of enjoyable and accessible various reading materials and accessories.

4) Parents should allow or expose their children to different reading materials to enhance their interest to read

In the future, a similar study using a large number of respondents may be undertaken to determine additional new results and findings that would improve the interest and motivation of pupils in reading.

\section{Conflicts of Interest}

The authors declare no conflicts of interest regarding the publication of this paper.

\section{References}

[1] Rimando, T. (2006) Whole School Approach to Mastery Reading and Writing for Successful Learning in the Secondary Level.

[2] Guthrie, J.T. and Wigfield, A. (2000) Engagement and Motivation in Reading. In: Handbook of Reading Research, Volume III, Erlbaum, New York, 403-422.

[3] Greeno, J.G. and the Middle School Mathematics through Applications Project Group (1998) The Situativity of Knowing, Learning, and Research. American Psychologist, 53, 5-26. https://doi.org/10.1037/0003-066X.53.1.5

[4] Lorch, R.F. and Van den Broek, R. (1997) Understanding Reading Comprehension: Current and Future Contributions of Cognitive Science. Contemporary Educational Psychology, 22, 213-247. https://doi.org/10.1006/ceps.1997.0931

[5] Deci, E.L. (1992) The Relation of Interest to the Motivation of Behavior: A Self-Determination Theory Perspective. Earlbum, Hillsdale.

[6] Mazzoni, F. (2000) Building toward Coherent Instruction. In: Baker, L., Dreher, J., and Guthrie, J.T., Eds., Engaging Young Readers. Promoting Achievement and Motivation, Guilford Press, New York, 209-237.

[7] Wentzel, K.R. (1991) Social and Academic Goals at School: Motivation and Achievement in Contrast. JAL, Grennwich.

[8] Celano, D. (2001) Access to Print in Low-Income and Middle-Income Communities. Reading Research Quarterly, 9, 5-24

[9] Chapman, J.W. and Tunmer, W.E. (2003) Reading Difficulties, Reading Related 
Self-Perceptions and Strategies for Overcoming Negative Self-Beliefs. Reading and Writing Quarterly, 9, 5-24. https://doi.org/10.1080/10573560308205

[10] Guiab, M.R. (2001) A Study on the Quality of Reading Instruction. Modern Teacher, 233.

[11] Meece, J.L. and Miller, S.D. (1999) Changes in Elementary School Children's Achievement Goals for Reading and Writing: Results of a Longitudinal and an Intervention Study. Scientific Studies of Reading, 3, 207-229. https://doi.org/10.1207/s1532799xssr0303_2

[12] Paul, M. and Doughlas, F. (2007) Exceptional Children. Scaling Early Reading Alternate Assessment with Statewide Measures. Exceptional Children, 73, 184-201.

[13] Pressley, M. (2002) Cognitive Science of Reading. Contemporary Educational Psychology, 22, 247-259.

[14] Quirk, M.P. (2004) Do Supplemental Remedial Reading Programs Address the Motivational Issue of Struggling Readers? An Analysis of Five Popular Programs. Reading Research and Instruction, 43, 1-19. https://doi.org/10.1080/19388070509558408

[15] Wigfeild, A. and Guthrie, J.T. (1997) Relations of Children's Motivation for Reading to the Amount and Breadth of Their Reading. Journal of Educational Psychology, 89, 420-432. https://doi.org/10.1037/0022-0663.89.3.420

[16] Kozulin, A., Gindis, B., Ageyev, V.S. and Miller, S.M. (2003) Vygotsky's Educational Theory in Cultural Context. Cambridge University Press, Cambridge. https://doi.org/10.1017/CBO9780511840975

[17] Metsala, J.L. (1997) An Examination of Word Frequency and Neighborhood Density in the Development of Spoken-Word Recognition. Memory and Cognition, 25, 47-56. https://doi.org/10.3758/BF03197284

[18] Bandura, A. (1997) Social Foundations of Thought and Action: A Social Cognitive Theory. Prentice Hall, Englewood Cliffs.

[19] Guthrie, J.T. and Schefer, W.D. (2001) Benefits of Opportunity to Read and Balanced Reading Instruction for Reading Achievement in a Statewide Improvement Program. Journal of Educational Research, 93, 211-225. https://doi.org/10.1080/00220670009598710

[20] Knobloch, S. and Carpentier, F.D. (2003) “Affective-News Theory" Effects of Narrative Structure on Suspense, Curiosity and Enjoyment While Reading News and Novels.

[21] Sofsian, D. (2009) The Importance of Reading.

[22] Stipek, D. (1996) Motivation and Instruction. In: Handbook of Educational Psychology, Simon and Schuster/McMillan, New York, 85-113.

[23] Wentzel, K.R. and Wigfield, A. (1998) Academic and Social Motivational Influences on Students' Academic Performance. Educational Psychology Review, 10, 155-175. https://doi.org/10.1023/A:1022137619834

[24] Guthrie, J.T., Schafer, W.D. and Huang, C.W. (2001) Benefits of Opportunity to Read and Balanced Instruction on the NAEP. The Journal of Educational Research, 94, 145-162. https://doi.org/10.1080/00220670109599912

[25] Cunningham, T., et al. (2002) The Effects of Reading Technologies on Literary Development of ESL Students (Poster Presentation).

[26] Vauras, F. and Maki, A. (2000) Teacher Perceptions and Students' Reading Motivation. Journal of Educational Psychology, 90, 210-223. 
[27] Lepola, J., Poskiparta, E., Laakkonen, E. and Niemi, P. (2005) Development of and Relationship between Phonological and Motivational Processes and Naming Speed in Predicting Word Recognition in Grade 1. Scientific Studies of Reading, 9, 367-399. https://doi.org/10.1207/s1532799xssr0904_3

[28] Eccles, J.S., Wigfield, A. and Schiefele, U. (1998) Motivation to Succeed. In: Damon, W. and Eisenberg, N., Eds., Handbook of Child Psychology: Social, Emotional, and Personality Development, John Wiley \& Sons Inc., Hoboken, NJ, US, 1017-1095.

[29] Chapman, J. (2000) Cognitive-Motivational Characteristics and Academic Achievement of Learning Disabled Children: Individual Differences and Their Implications for Treatment. Academic Press, New York.

[30] Gambrell, L.B. (1996) Elementary Students' Motivation to Read. Reading Research Report No. 52. 